\title{
Springer
}

This document is the Accepted Manuscript version of a Published Work that appeared in final form in Journal of Materials Science, copyright (C) Springer after peer review and technical editing by the publisher.

To access the final edited and published work see http://link.springer.com/article/10.1007/s10973-015$\underline{5201-0 .}$.

\section{Thermal decomposition of ammonium molybdates}

\author{
Teodóra Nagyné Kovács ${ }^{1}$, Dávid Hunyadi ${ }^{1}$, Alex Leandro Andrade de Lucena ${ }^{1}$, Imre Miklós \\ Szilágyi ${ }^{1,2 *}$
}

${ }^{1}$ Department of Inorganic and Analytical Chemistry, Budapest University of Technology and Economics, H-1111 Budapest, Szt. Gellért tér 4. Hungary

${ }^{2}$ MTA-BME Technical Analytical Chemistry Research Group, Hungarian Academy of Sciences, H1111 Budapest, Szt. Gellért tér 4. Hungary

Corresponding author: imre.szilagyi@,mail.bme.hu

\section{Keywords}

Ammonium molybdate, TG/DTA, MS, XRD, FTIR, SEM

\begin{abstract}
The thermal behavior of ammonium molybdates, i.e. $\left(\mathrm{NH}_{4}\right)_{6} \mathrm{Mo}_{7} \mathrm{O}_{24} \cdot 4 \mathrm{H}_{2} \mathrm{O}$ (1) and $\left(\mathrm{NH}_{4}\right)_{2} \mathrm{MoO}_{4}(\mathbf{2})$, was studied in inert $\left(\mathrm{N}_{2}\right)$ and oxidizing (air) atmospheres by TG/DTA-MS, XRD, FTIR and SEM. The thermal decomposition sequence of $\mathbf{2}$ had similarities to $\mathbf{1}$; however, there were significant differences as well. When both of them were annealed, $\mathrm{NH}_{3}$ and $\mathrm{H}_{2} \mathrm{O}$ were released parallel, and in air the asevolved $\mathrm{NH}_{3}$ was burnt partially into $\mathrm{NO}$ and $\mathrm{N}_{2} \mathrm{O}$. In both atmospheres, while $\mathbf{1}$ decomposed in four steps, the thermal decomposition of $\mathbf{2}$ involved 5 steps. In the case of $\mathbf{1}$, the intermediate products were $\left(\mathrm{NH}_{4}\right)_{8} \mathrm{Mo}_{10} \mathrm{O}_{34},\left(\mathrm{NH}_{4}\right)_{2} \mathrm{Mo}_{4} \mathrm{O}_{13}$ and h- $\mathrm{MoO}_{3}$. In contrast, the decomposition intermediates of 2 were
\end{abstract}


$\left(\mathrm{NH}_{4}\right)_{2} \mathrm{Mo}_{3} \mathrm{O}_{10},\left(\mathrm{NH}_{4}\right)_{2} \mathrm{Mo}_{2} \mathrm{O}_{7},\left(\mathrm{NH}_{4}\right)_{2} \mathrm{Mo}_{4} \mathrm{O}_{13}$ and h- $\mathrm{MoO}_{3}$. By both 1 and 2 , the final product was dominated by o- $\mathrm{MoO}_{3}$, accompanied with small amount of $\mathrm{Mo}_{4} \mathrm{O}_{11}$ in $\mathrm{N}_{2}$, which was absent in air. Most decomposition steps were endothermic, except for the last step around $400{ }^{\circ} \mathrm{C}$, where crystallization from the residual amorphous phase had an exothermic heat effect. In addition, the combustion of $\mathrm{NH}_{3}$ also changed the DTA curve into exothermic in some cases. The morphology of the final products was characterized by $1-5 \mu \mathrm{m}$ sheet-like particles, except for annealing 2 in $\mathrm{N}_{2}$, when 0.5 $1 \mu \mathrm{m}$ thick and 5-10 $\mu \mathrm{m}$ long needle-shaped particles were detected.

\section{Introduction}

Ammonium molybdate terahydrate or ammonium heptamolybdate, i.e. $\left(\mathrm{NH}_{4}\right)_{6} \mathrm{Mo}_{7} \mathrm{O}_{24} \cdot 4 \mathrm{H}_{2} \mathrm{O}$ (1) is widely used for the preparation of molybdenum oxides, reduced molybdenum oxides, mixed molybdenum oxides or supported molybdenum oxide catalysts, and it can be also a precursor for molybdenum carbide or molybdenum metal. MoOx catalysts have applications in various catalytic reactions, e.g. partial oxidation for light alkenes, hydrotreating, hydrodenitrogenation, or hydrodesulfurisation [1-5]. Molybdenum carbide is also applied as a catalyst for e.g. hydrogenation reactions [6-7]. Metallic molybdenum offers excellent mechanical, thermal and electrical properties and good corrosion resistance which makes it attractive for electronics, metallurgical, aerospace and electrical industries [8].

The structure of $\left(\mathrm{NH}_{4}\right)_{6} \mathrm{Mo}_{7} \mathrm{O}_{24} \cdot 4 \mathrm{H}_{2} \mathrm{O}$ is composed of monomers of seven distorted, edge-sharing, molybdenum-oxygen octahedra. The thermal behavior of $\left(\mathrm{NH}_{4}\right)_{6} \mathrm{Mo}_{7} \mathrm{O}_{24} \cdot 4 \mathrm{H}_{2} \mathrm{O}$ has been studied in a great number of papers [9-38]. The role of decompositions conditions (e.g. atmosphere, heating rate,

presence of dopants, influence of possible support materials) have been investigated in detail. The reason for this increased interest is that the various $\mathrm{MoOx}$ materials, molybdenum carbide and molybdenum metal can be easily obtained by the thermal treatment of $\left(\mathrm{NH}_{4}\right)_{6} \mathrm{Mo}_{7} \mathrm{O}_{24} \cdot 4 \mathrm{H}_{2} \mathrm{O}$, and their application properties depends strongly on the structure, composition and morphology of the products, which are then determined by the circumstances of the annealing of the precursor [39].

However, there is another ammonium molybdate, i.e. $\left(\mathrm{NH}_{4}\right)_{2} \mathrm{MoO}_{4}$ (2), called ammonium orthomolybdate, which has a much simpler structure and composition [40]. It is mostly used as a corrosion inhibitor and can be also an intermediate to gain Mo from its ores [40]. Interestingly, the thermal behavior of $\left(\mathrm{NH}_{4}\right)_{2} \mathrm{MoO}_{4}$ has not been studied in detail yet, to the best of our knowledge. In order to use it also as a possible precursor for $\mathrm{MoOx}$ compounds, it is important to obtain information about its thermal properties. 
Hence, in this study our aim was to explore the thermal decomposition of $\left(\mathrm{NH}_{4}\right)_{2} \mathrm{MoO}_{4}$, and also study the thermal properties of $\left(\mathrm{NH}_{4}\right)_{6} \mathrm{Mo}_{7} \mathrm{O}_{24} \cdot 4 \mathrm{H}_{2} \mathrm{O}$ for comparison. Thus, the annealing of the two materials was studied both in inert $\left(\mathrm{N}_{2}\right)$ and oxidizing (air) atmospheres. The thermal events were followed by simultaneous thermogravimetry and differential thermal analysis (TG/DTA) and also by evolved gas analysis performed by mass spectrometer (EGA-MS) coupled on-line to the TG/DTA device. The changes in morphology, structure and bonds were investigated by scanning electron microscopy (SEM), X-ray powder diffraction (XRD), and infrared spectroscopy (FTIR), respectively.

\section{Experimental}

The $\left(\mathrm{NH}_{4}\right)_{6} \mathrm{Mo}_{7} \mathrm{O}_{24} \cdot 4 \mathrm{H}_{2} \mathrm{O}(\mathbf{1})$ and $\left(\mathrm{NH}_{4}\right)_{2} \mathrm{MoO}_{4}$ (2) samples were obtained from Sigma-Aldrich, and they were used as received.

SEM images were recorded by a JEOL JSM-5500LV scanning electron microscope.

Powder XRD patterns were measured on a PANalytical X'pert Pro MPD X-ray diffractometer using Cu $\mathrm{K}_{\alpha}$ radiation.

FTIR spectra were obtained by an Excalibur Series FTS 3000 (Biorad) FTIR spectrophotometer in the range of $400-4000 \mathrm{~cm}^{-1}$ in $\mathrm{KBr}$ pellets.

The thermal decomposition of the samples was studied by a TG/DTA-MS apparatus, which consisted of an STD 2960 Simultaneous TGA/DTA (TA Instruments Inc.) thermal analyzer and a Thermostar GSD 200 (Balzers Instruments) quadrupole mass spectrometer. On-line coupling between the two parts was provided through a heated $\left(T=200^{\circ} \mathrm{C}\right) 1 \mathrm{~m} \mathrm{100 \%}$ methyl deactivated fused silica capillary tube with inner diameter of $0.15 \mathrm{~mm}$. A mass range between $\mathrm{m} / z=1-200$ was monitored by scan mode. During the measurements an open platinum crucible, a heating rate of $10{ }^{\circ} \mathrm{C} \mathrm{min}^{-1}$, sample sizes of 5 -

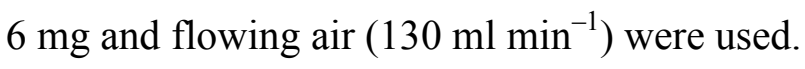

\section{Results and discussion}

\section{Characterization of 1}

According to SEM images (Fig. 1a) sample 1 consisted of irregularly shaped 10-50 $\mu \mathrm{m}$ aggregated particles. The sample was made up only by $\left(\mathrm{NH}_{4}\right)_{6} \mathrm{Mo}_{7} \mathrm{O}_{24} \cdot 4 \mathrm{H}_{2} \mathrm{O}(\mathrm{ICDD} 27-1013)$, and there were no impurities detected in the X-ray powder diffractograms (Fig. 2). In the FTIR spectrum (Fig. 3) the 
bands below $1000 \mathrm{~cm}^{-1}$ were assigned to various Mo-O lattice vibrations, characteristic to polymolybdates [41]. The N-H and O-H deformation bands of ammonium ions and water appeared at 1400 and $1630 \mathrm{~cm}^{-1}$, respectively; while the $\mathrm{O}-\mathrm{H}$ and $\mathrm{N}-\mathrm{H}$ stretching vibrations were detected at 3135 and $3570 \mathrm{~cm}^{-1}[42-43]$.

\section{Thermal decomposition of 1 in $N_{2}$}

The first decomposition step was observed between $25-180{ }^{\circ} \mathrm{C}$, and it was accompanied by an endothermic heat effect (Fig. 4). $\mathrm{NH}_{3}$ and $\mathrm{H}_{2} \mathrm{O}$ were released parallel. Due to their evolution the intensity of the N-H and O-H bands in the FTIR spectrum decreased to some extent. The initial crystal structure changed completely and a new polymolybdate phase, i.e. $\left(\mathrm{NH}_{4}\right)_{8} \mathrm{Mo}_{10} \mathrm{O}_{34}(\mathrm{ICDD} 37-0381)$ appeared (93.3 and 93.2\% theoretical and measured remaining mass), as evidenced by XRD and FTIR. In the second decomposition step $\left(180-270{ }^{\circ} \mathrm{C}\right.$ ) in an endothermic reaction again $\mathrm{NH}_{3}$ and $\mathrm{H}_{2} \mathrm{O}$ evolved, and the $\left(\mathrm{NH}_{4}\right)_{8} \mathrm{Mo}_{10} \mathrm{O}_{34}$ phase transformed into $\left(\mathrm{NH}_{4}\right)_{2} \mathrm{Mo}_{4} \mathrm{O}_{13}$ (ICDD 11-4665) (88.9 and $88.7 \%$ theoretical and measured remaining mass). The N-H and O-H FTIR peaks reduced in intensity considerably and the Mo-O lattice vibration region was also modified.

In the third, endothermic decomposition step $\left(270-370{ }^{\circ} \mathrm{C}\right.$ ) the parallel evolution of $\mathrm{NH}_{3}$ and $\mathrm{H}_{2} \mathrm{O}$ continued, and the $\mathrm{O}-\mathrm{H}$ and $\mathrm{N}-\mathrm{H}$ bands in the infrared spectrum disappeared almost completely. The crystal structure changed and a mixture of two phases was present. Traces of hexagonal molybdenum oxide, i.e. h- $\mathrm{MoO}_{3}$ (ICDD 21-0569) were observed, but besides this phase already orthorhombic molybdenum oxide, i.e. o- $\mathrm{MoO}_{3}$ (ICDD 12-8070) also appeared, which was the main component at this temperature.

In the last step $\left(370-400{ }^{\circ} \mathrm{C}\right)$ in a slightly exothermic reaction the amount of o- $\mathrm{MoO}_{3}$ increased (81.5 and $81.2 \%$ theoretical and measured remaining mass). The h- $\mathrm{MoO}_{3}$ phase disappeared and a partially reduced molybdenum oxide, i.e. $\mathrm{Mo}_{4} \mathrm{O}_{11}$ (ICDD 89-8980) formed, which was responsible for the lower measured remaining mass than the theoretical value for $\mathrm{MoO}_{3}$. FTIR also revealed the formation of molybdenum oxide [44].

At the end of the annealing the morphology changed significantly compared to the starting material (Fig. 1b). At $700{ }^{\circ} \mathrm{C}$ the product was built up by $1-5 \mu \mathrm{m}$ particles and sheets.

\section{Thermal decomposition of 1 in air}


The first two steps of the thermal decomposition of $\mathbf{1}$ in air were similar to those in $\mathrm{N}_{2}$. From the starting material in the first endothermic step $\left(25-180{ }^{\circ} \mathrm{C}\right) \mathrm{NH}_{3}$ and $\mathrm{H}_{2} \mathrm{O}$ were released (Fig. 5) and $\left(\mathrm{NH}_{4}\right)_{8} \mathrm{Mo}_{10} \mathrm{O}_{34}$ formed (Fig. 6). Then between 180 and $270{ }^{\circ} \mathrm{C}$ this phase transformed into $\left(\mathrm{NH}_{4}\right)_{2} \mathrm{Mo}_{4} \mathrm{O}_{13}$ in and endothermic reaction, accompanied by the release $\mathrm{NH}_{3}$ and $\mathrm{H}_{2} \mathrm{O}$. In the FTIR spectra (Fig. 7) the changes were also very similar to those in air; the most remarkable was the decrease of the intensity of the $\mathrm{N}-\mathrm{H}$ and $\mathrm{O}-\mathrm{H}$ vibrations, and as the crystal structure changed, the lattice vibration region below $1000 \mathrm{~cm}^{-1}$ was modified. The only significant difference was that in air in the first decomposition step a small amount of the as-released $\mathrm{NH}_{3}$ was oxidized thermally to NO. Due to the elevated temperature, in the second decomposition step a larger portion of the as-evolved $\mathrm{NH}_{3} \mathrm{Was}$ burnt, and besides $\mathrm{NO}$ also $\mathrm{N}_{2} \mathrm{O}$ was detected as combustion product. Although the oxidation of $\mathrm{NH}_{3}$ is an exothermic process [45-47], still the endothermic heat effect of the decomposition of the solid phase was dominant on the DTA curve; thus, here again an intense endothermic DTA peak was observed at $234^{\circ} \mathrm{C}$.

It must be mentioned that $\mathrm{N}_{2} \mathrm{O}$ and $\mathrm{NO}$ formation might be also the consequence of $\mathrm{NH}_{4} \mathrm{NO}_{3}$ intermediate formation and decomposition to some extent. Such phenomenon was observed in case of other ammonium salts of other oxometallates (e.g. permanganates, vanadates, etc.), when the metal oxide type intermediates could catalyze the oxidation reaction [48-52].

In contrast to inert atmosphere, in air in the third step $\left(270-350{ }^{\circ} \mathrm{C}\right)$ the $\left(\mathrm{NH}_{4}\right)_{2} \mathrm{Mo}_{4} \mathrm{O}_{13}$ phase transformed only into o- $\mathrm{MoO}_{3}$. The absence of $\mathrm{h}-\mathrm{MoO}_{3}$ at the end of the third decomposition step is explained by annealing in oxidizing atmosphere. Due to annealing in air, besides $\mathrm{NH}_{3}$ and $\mathrm{H}_{2} \mathrm{O}$, also $\mathrm{NO}$ and $\mathrm{N}_{2} \mathrm{O}$ were detected, similar to the second decomposition step.

In the fourth step, similar to $\mathrm{N}_{2}$ atmosphere, a small exothermic heat effect was observed. However, here in the final solid product only $\mathrm{o}-\mathrm{MoO}_{3}$ was observed without the partially reduced $\mathrm{Mo}_{4} \mathrm{O}_{11}$, in contrast to what was observed in inert atmosphere; thus, here the measured remaining mass was equal to the theoretical $81.5 \%$ value. Before and after the exothermic reaction the solid phase contained o$\mathrm{MoO}_{3}$, and the only difference was that the sample became more crystalline at the end of the fourth step. Hence, the exothermic heat effect is explained by the further crystallization of o- $\mathrm{MoO}_{3}$ from the residual amorphous part of the sample at $350{ }^{\circ} \mathrm{C}$.

The morphology of the final product was characterized again by 1-5 $\mu \mathrm{m}$ particles, however, here their size was even smaller than in $\mathrm{N}_{2}$, and most of them were sheet-like.

\section{Characterization of 2}


Sample 2 was built up by 1-10 $\mu$ m particles, which were aggregated into much larger blocks (Fig. 8a). Thus, the particles size of sample $\mathbf{2}$ was much smaller than that of $\mathbf{1}$. The sample consisted of only $\left(\mathrm{NH}_{4}\right)_{2} \mathrm{MoO}_{4}($ ICDD 12-2248) with no impurities. The FTIR spectrum was similar to 1; however, in 2 the $\mathrm{O}-\mathrm{H}$ deformation vibration band $\left(1630 \mathrm{~cm}^{-1}\right)$ was more intense compared to the $\mathrm{N}-\mathrm{H}$ deformation peak $\left(1400 \mathrm{~cm}^{-1}\right)$. The Mo-O vibration region below $1000 \mathrm{~cm}^{-1}$ was also somewhat different, corresponding to the difference in the crystal structures of $\mathbf{1}$ and $\mathbf{2}$.

\section{Thermal decomposition of 2 in $N_{2}$}

Though the structure and composition of $\mathbf{2}$ was quite simple, nevertheless its thermal decomposition was quite complex, which is in contrast to e.g. $\left(\mathrm{NH}_{4}\right)_{2} \mathrm{WS}_{2}$, which has similar structure, and its thermal behaviour is not complicated, and involves only few decomposition steps and intermediates [53].

The mass loss $(17.6 \%)$ in the first decomposition $\left(25-200{ }^{\circ} \mathrm{C}\right)$ step of 2 in $\mathrm{N}_{2}$ (Fig. 11) was much larger than in the case of $\mathbf{1}$. Similarly, $\mathrm{NH}_{3}$ and $\mathrm{H}_{2} \mathrm{O}$ were released parallel in an endothermic reaction, and in the FTIR spectrum the intensity of the $\mathrm{N}-\mathrm{H}$ and $\mathrm{O}-\mathrm{H}$ peaks decreased to some extent. The intermediate sample after the first decomposition step consisted of different phases, compared to 1, i.e. $\left(\mathrm{NH}_{4}\right)_{2} \mathrm{Mo}_{3} \mathrm{O}_{10}$ (ICDD 09-9568) and a small amount of $\left(\mathrm{NH}_{4}\right)_{2} \mathrm{Mo}_{2} \mathrm{O}_{7}$ (ICDD 12-7094) were detected at $200{ }^{\circ} \mathrm{C}$ in the case of annealing 2 in $\mathrm{N}_{2}$.

In the second decomposition step $\left(200-230{ }^{\circ} \mathrm{C}\right)$, accompanied with a small evolution of $\mathrm{NH}_{3}$ and $\mathrm{H}_{2} \mathrm{O}$ and $0.7 \%$ mass loss, in an endothermic reaction the $\left(\mathrm{NH}_{4}\right)_{2} \mathrm{Mo}_{2} \mathrm{O}_{7}$ content of the sample at $200{ }^{\circ} \mathrm{C}$ transformed into $\left(\mathrm{NH}_{4}\right)_{2} \mathrm{Mo}_{3} \mathrm{O}_{10}$. Thus, the sample at $230{ }^{\circ} \mathrm{C}$ contained only $\left(\mathrm{NH}_{4}\right)_{2} \mathrm{Mo}_{3} \mathrm{O}_{10}(82.3$ and $81.7 \%$ theoretical and measured remaining mass).

The third decomposition step $\left(230-280^{\circ} \mathrm{C}\right)$ was also characterized by a small mass loss $(2.4 \%)$. Here again $\mathrm{NH}_{3}$ and $\mathrm{H}_{2} \mathrm{O}$ were detected as gaseous decomposition products. The sample at $280{ }^{\circ} \mathrm{C}$ contained only $\left(\mathrm{NH}_{4}\right)_{2} \mathrm{Mo}_{4} \mathrm{O}_{13}(80.1$ and $79.4 \%$ theoretical and measured remaining mass), which was also the only constituent of the intermediate sample at $270{ }^{\circ} \mathrm{C}$ during the thermal decomposition of $\mathbf{1}$ in $\mathrm{N}_{2}$. Therefore, from this stage the thermal behavior of $\mathbf{2}$ has become similar to $\mathbf{1}$.

Accordingly, sample 2 almost completely lost its $\mathrm{NH}_{4}{ }^{+}$and $\mathrm{H}_{2} \mathrm{O}$ content at $370{ }^{\circ} \mathrm{C}$ in an endothermic reaction, and hence the $\mathrm{N}-\mathrm{H}$ and $\mathrm{O}-\mathrm{H}$ deformation and stretching FTIR peaks basically disappeared. As the main constituent of the intermediate sample at $370{ }^{\circ} \mathrm{C} \mathrm{o}-\mathrm{MoO}_{3}$ was detected; in addition, traces of h- $\mathrm{MoO}_{3}$ were also present.

Then, in the final decomposition step $\left(370-420{ }^{\circ} \mathrm{C}\right)$ the $\mathrm{h}-\mathrm{MoO}_{3}$ disappeared, the $\mathrm{o}-\mathrm{MoO}_{3}$ became more crystalline accompanied by an exothermic heat effect (exothermic DTA peak at $400{ }^{\circ} \mathrm{C}$ ) and also the 
$\mathrm{Mo}_{4} \mathrm{O}_{11}$ phase was detected to some extent, just as in the case of $\mathbf{1}$. Accordingly, the remaining was was a bit lower $(73.3 \%)$ than what expected for pure $\mathrm{MoO}_{3}(73.5 \%)$

In contrast to $\mathbf{1}$, the morphology of the final decomposition product of $\mathbf{2}$ was dominated by needle like particles, which were 0.5-1 $\mu \mathrm{m}$ thick and 5-10 $\mu \mathrm{m}$ long (Fig. 8b).

\section{Thermal decomposition of 2 in air}

The thermal decomposition of $\mathbf{2}$ in air was a combination of the thermal behavior of $\mathbf{2}$ in $\mathrm{N}_{2}$ and the thermal decomposition of $\mathbf{1}$ in air.

In the first decomposition step $\left(25-205^{\circ} \mathrm{C}\right), \mathrm{NH}_{3}$ and $\mathrm{H}_{2} \mathrm{O}$ was released parallel and also small amount of NO was detected (Fig. 12). The mass loss (15.8\%) was similar as in $\mathrm{N}_{2}$, and the formed crystalline phases were also similar, i.e. $\left(\mathrm{NH}_{4}\right)_{2} \mathrm{Mo}_{3} \mathrm{O}_{10}$ and $\left(\mathrm{NH}_{4}\right)_{2} \mathrm{Mo}_{2} \mathrm{O}_{7}$ (Fig. 13). The intensity of the $\mathrm{N}-\mathrm{H}$ and $\mathrm{O}-\mathrm{H}$ stretching and deformation modes decreased to some extent, and there were also changes in the Mo-O vibration region below $1000 \mathrm{~cm}^{-1}$, according to the change in the crystalline structure (Fig. 14). In the second $\left(205-230{ }^{\circ} \mathrm{C}\right)$ and third decomposition $\left(230-270{ }^{\circ} \mathrm{C}\right)$ steps $\mathrm{NH}_{3}$ and $\mathrm{H}_{2} \mathrm{O}$ evolved (endothermic DTA peaks at 214 and $242{ }^{\circ} \mathrm{C}$, respectively), and at $270{ }^{\circ} \mathrm{C}$ the solid sample was composed of mostly $\left(\mathrm{NH}_{4}\right)_{2} \mathrm{Mo}_{4} \mathrm{O}_{13}$.

In the fourth decomposition step $\left(270-370{ }^{\circ} \mathrm{C}\right)$ the sample transformed into o- $\mathrm{MoO}_{3}$. Here the combustion of the as-released $\mathrm{NH}_{3}$ was so intensive that the DTA peak started as endothermic (endothermic DTA peak at $317^{\circ} \mathrm{C}$ ) due the decomposition of the solid materials, but then it changed into exothermic at the second part of the decomposition step (exothermic DTA peak at $343{ }^{\circ} \mathrm{C}$ ). The XRD pattern of the intermediate obtained at $325^{\circ} \mathrm{C}$ showed traces of $\mathrm{h}-\mathrm{MoO}_{3}$, but by the end of this step these peaks disappeared.

In the last decomposition step the amorphous part of the sample transformed into o- $\mathrm{MoO}_{3}$ in an exothermic reaction (small exothermic DTA peak at $420^{\circ} \mathrm{C}$ ) and hence the XRD peaks of this phase became stronger and narrower, and FTIR also showed the characteristic bands of the o- $\mathrm{MoO}_{3}$ phase.

Unlike the annealing of $\mathbf{2}$ in $\mathrm{N}_{2}$, the morphology of the final product of $\mathbf{2}$ in air was built up again by sheet-like particle of 1-5 $\mu \mathrm{m}$ (Fig. 8c), similar to when 1 was annealed in $\mathrm{N}_{2}$ and air.

\section{Conclusion}

The thermal decomposition of $\left(\mathrm{NH}_{4}\right)_{6} \mathrm{Mo}_{7} \mathrm{O}_{24} \cdot 4 \mathrm{H}_{2} \mathrm{O}(\mathbf{1})$ and $\left(\mathrm{NH}_{4}\right)_{2} \mathrm{MoO}_{4}(2)$ were studied extensively in inert $\left(\mathrm{N}_{2}\right)$ and oxidizing (air) atmospheres by TG/DTA-MS, XRD, FTIR and SEM. 
1 decomposed in four steps in $\mathrm{N}_{2}$, where $\mathrm{NH}_{3}$ and $\mathrm{H}_{2} \mathrm{O}$ were released parallel. The intermediate products were $\left(\mathrm{NH}_{4}\right)_{8} \mathrm{Mo}_{10} \mathrm{O}_{34},\left(\mathrm{NH}_{4}\right)_{2} \mathrm{Mo}_{4} \mathrm{O}_{13}$ and h- $\mathrm{MoO}_{3}$, while the final sample was dominated by o- $\mathrm{MoO}_{3}$, accompanied with a small amount of the partially reduced $\mathrm{Mo}_{4} \mathrm{O}_{11}$ phase. In air the asreleased $\mathrm{NH}_{3}$ was oxidized thermally into $\mathrm{NO}$ and $\mathrm{N}_{2} \mathrm{O}$. Due to the oxidizing atmosphere the only final product was $\mathrm{o}-\mathrm{MoO}_{3}$. The hexagonal molybdenum oxide phase (h- $\mathrm{MoO}_{3}$ ) and the partially reduced molybdenum oxide $\left(\mathrm{Mo}_{4} \mathrm{O}_{11}\right)$ in air were not observed.

The thermal decomposition sequence of $\mathbf{2}$ had similarities to $\mathbf{1}$; however, there were significant differences as well. In addition, though the structure and composition of $\mathbf{2}$ was quite simple, its thermal decomposition was complex. In $\mathrm{N}_{2}$ the decomposition intermediates were $\left(\mathrm{NH}_{4}\right)_{2} \mathrm{Mo}_{3} \mathrm{O}_{10}$ and $\left(\mathrm{NH}_{4}\right)_{2} \mathrm{Mo}_{2} \mathrm{O}_{7}$ in the first two steps in contrast to $\mathbf{1}$, where only $\left(\mathrm{NH}_{4}\right)_{8} \mathrm{Mo}_{10} \mathrm{O}_{34}$ observed as a decomposition intermediate in this region. Then at $270-280{ }^{\circ} \mathrm{C}\left(\mathrm{NH}_{4}\right)_{2} \mathrm{Mo}_{4} \mathrm{O}_{13}$ was a common intermediate for both 1 and 2. The final product was o- $\mathrm{MoO}_{3}$ together with a small amount of $\mathrm{Mo}_{4} \mathrm{O}_{11}$, similar to $\mathbf{1}$. The thermal decomposition of $\mathbf{2}$ in air was a combination of the thermal behavior of $\mathbf{2}$ in $\mathrm{N}_{2}$ and the thermal decomposition of $\mathbf{1}$ in air. The decomposition intermediates were the same as for $\mathbf{2}$ in $\mathrm{N}_{2}$, i.e. $\left(\mathrm{NH}_{4}\right)_{2} \mathrm{Mo}_{3} \mathrm{O}_{10},\left(\mathrm{NH}_{4}\right)_{2} \mathrm{Mo}_{2} \mathrm{O}_{7},\left(\mathrm{NH}_{4}\right)_{2} \mathrm{Mo}_{4} \mathrm{O}_{13}$ and h- $\mathrm{MoO}_{3}$, and the final product was highly crystalline $\mathrm{o}-\mathrm{MoO}_{3}$ without the presence of $\mathrm{Mo}_{4} \mathrm{O}_{11}$. Similar to the decomposition of $\mathbf{1}$ in air, the asevolved $\mathrm{NH}_{3}$ was burnt partially into $\mathrm{NO}$ and $\mathrm{N}_{2} \mathrm{O}$.

In the case of both 1 and 2, most decomposition steps were endothermic. An exception was the last step for both phases (around $400{ }^{\circ} \mathrm{C}$ ), where the increase in the crystallinity of the samples through the formation of $\mathrm{o}-\mathrm{MoO}_{3}$ from the residual amorphous phase at the end of the previous step had exothermic heat effect. In addition, the combustion of $\mathrm{NH}_{3}$ was so intensive that, when $\mathbf{2}$ was annealed in air, after $330{ }^{\circ} \mathrm{C}$ the DTA curve changed from endothermic into exothermic.

While 1 consisted of irregularly shaped 10-50 $\mu \mathrm{m}$ aggregated particles, 2 was built up by 1-10 $\mu \mathrm{m}$ particles. Nevertheless, after annealing 1 in air and $\mathrm{N}_{2}$ and heating $\mathbf{2}$ in air the final products were composed of 1-5 $\mu \mathrm{m}$ particles and sheets. In contrast, when 2 was annealed in $\mathrm{N}_{2}$ at $700{ }^{\circ} \mathrm{C}$, the sample was dominated by $0.5-1 \mu \mathrm{m}$ thick and 5-10 $\mu \mathrm{m}$ long needle like particles.

\section{Acknowledgements}

I. M. Szilágyi thanks for a János Bolyai Research Fellowship of the Hungarian Academy of Sciences. An OTKA-PD-109129 grant is acknowledged. 


\section{References}

[1] Liu H, Liu C, Yin C, Chai Y, Li Y, Liu D, Liu B, Li X, Wang Y, Li X. Preparation of highly active unsupported nickel-zinc-molybdenum catalysts for the hydrodesulfurization of dibenzothiophene. Appl Catal B. 2015;174-175:264-276.

[2] Adamiak J. Controlled nitration of anisole over $\mathrm{HNO}_{3} / \mathrm{PO}_{4} / \mathrm{MoO}_{3} / \mathrm{SiO}_{2} /$ solvent systems. J Mol Catal A. 2015;407:81-86.

[3] Ressler T, Walter A, Huang ZD, Bensch W. Structure and properties of a supported $\mathrm{MoO}_{3}-\mathrm{SBA}_{-}$ 15 catalyst for selective oxidation of propene. J Catal. 2008;254:170-179.

[4] Grasselli RK. Advances and future trends in selective oxidation and ammoxidation catalysis. Catal Today. 1999;49:141-153.

[5] Haber J, Lalik E. Catalytic properties of $\mathrm{MoO}_{3}$ revisited. Catal Today. 1997;33:119-137.

[6] Zaman S, Smith K. A Review of Molybdenum Catalysts for Synthesis Gas Conversion to Alcohols: Catalysts, Mechanisms and Kinetics. Catal Rev Sci Eng. 2012;54:41-132.

[7] Kim HG, Lee KH, Lee JS. Carbon monoxide hydrogenation over molybdenum carbide catalysts. Res Chem Intermed. 2000;26:427-443.

[8] Saji VS, Lopatin SI, editor. Molybdenum and its Compounds: Applications, Electrochemical Properties and Geological Implications. New York: Nova Science Publishers; 2014.

[9] Hegedűs AJ, Sasvári K, Neugebauer J. Thermo- und röntgenanalytischer Beitrag zur Reduktion des Molybdäntrioxyds und zur Oxydation bzw. Nitrierung des Molybdäns. Z Anorg Allg Chemie. 1957;293:56-83.

[10] Onchi M, Ma E. An application of the omegatron mass spectrometer to thermal decomposition studies. J Phys Chem 1963;67:2240-2241.

[11] Ma E. Thermal decomposition of ammonium polymolybdates I. Bull Chem Soc Jpn 1964;37:171-175.

[12] Ma E. Thermal decomposition of ammonium polymolybdates II. Bull Chem Soc Jpn. 1964;37:648-653.

[13] Schwing-Weill MJ. Bull Soc Chim Fr. 1967;10:3795-3798.

[14] Kiss AB, Gadó P, Asztalos I, Hegedűs AJ. Acta Chim Acad Sci Hung. 1970;66:235-249.

[15] Louisy A, Dunoyer JM. Thermal decomposition of ammonium paramolybdate. Bull Soc Chim Fr. 1970;67:1390-1394.

[16] Bhatnagar IK, Chakrabarty DK, Biswas AB. Thermal decomposition of ammonium vanadate, ammonium molybdate, and ammonium tungstate. Indian J Chem. 1972;10:1025-1028. 
[17] Hanafi ZM. Khilla MA, Askar MH. The thermal decomposition of ammonium heptamolybdate. Thermochim Acta. 1981;45:221-232.

[18] Isa $\mathrm{K}$, Ishimura $\mathrm{H}$. Thermal decomposition studies of ammonium heptamolybdate(6-) tetrahydrate by means of high-temperature oscillating x-ray diffraction with a rotating anode type large capacity generator. Bull Chem Soc Jpn. 1981;54:3628-3634.

[19] Topic M, Mogus-Milankovic A. A multiple thermal-analysis of ammonioum heptamolybdate tetrahydrate. Chroatica Chem Acta 1984;57:75-83.

[20] Sharma IB, Batra S. Characterization and thermal investigations of ammonium heptamolybdate. J Therm Anal. 1987;34:1273-1281.

[21] Yong WJ. The GC study of the thermal decomposition of ammonium paramolybdate tetrahydrate in a hydrogen atmosphere. Thermochim Acta 1990;158:183-186.

[22] Shashkin DP, Shiryaev PA, Kutyrev MY, Krylov OV. Peculiarities of the effect of vanadium ions on molybdena development under prereaction conditions. Kin Catal. 1993;34:302-306.

[23] Halawy SA, Mohamed MA. Characterization of unsupported molybdenum oxide-cobalt oxide catalysts. J Chem Tech Biotechnol. 1993;58:237-245.

[24] Said AA, Halawy SA. Effects of alkali metal ions on the thermal decomposition of ammonium heptamolybdate tetrahydrate. J Therm Anal. 1994;41:1075-1090.

[25] Said AA. Mutual influences between ammonium heptamolybdate and g-alumina during their thermal treatments. Thermochim Acta. 1994;236:93-104.

[26] Cabello CI, Botto IL, Thomas HJ. Reducibility and thermal behavior of some Anderson phases. Thermochim Acta. 1994;232:183-193.

[27] Bi M, Li H, Pan WP, Lloyd WG, Davis BH. Thermal studies of $\left(\mathrm{NH}_{4}\right)_{2} \mathrm{Cr}_{2} \mathrm{O}_{7},\left(\mathrm{NH}_{4}\right)_{2} \mathrm{WO}_{4}$ and $\left(\mathrm{NH}_{4}\right)_{6} \mathrm{Mo} \mathrm{O}_{24} \cdot 4 \mathrm{H}_{2} \mathrm{O}$ deposited on $\mathrm{ZrO}_{2}$. Thermochima Acta. 1996;284:153-160.

[28] Valmalette JC, Houriet R, Hofmann H, Gavarri JR. Formation of $\mathrm{N}_{2} \mathrm{O}$ during the thermal decomposition of ammonium salts $\left(\mathrm{NH}_{4}\right)_{\mathrm{a}} \mathrm{M}_{\mathrm{x}} \mathrm{O}_{\mathrm{y}}(\mathrm{M}=\mathrm{V}, \mathrm{Cr}$, Mo and W). Eur J Solid State Inorg Chem. 1997;34:317-329.

[29] Li JL, Inui T. Characterization of precursors of methanol synthesis catalysts, copper/zinc/aluminum oxides, precipitated at different $\mathrm{pHs}$ and temperatures. Appl Catal A. 1996;137:105-117.

[30] Zhoulan Y, Xinhai L, Qiyuan C. Study on the kinetics of the thermal decompositions of ammonium molybdates. Thermochim Acta. 2000;352-353:107-110.

[31] Thomazeau C, Martin V, Afanasiev P. Effect of support on the thermal decomposition of $\left(\mathrm{NH}_{4}\right)_{6} \mathrm{Mo}_{7} \mathrm{O}_{24} \cdot 4 \mathrm{H}_{2} \mathrm{O}$ in the inert gas atmosphere. Appl Cat A. 2000;199:61-72. 
[32] Shaheen WM, Selim MM. Thermal Decompositions of Pure and Mixed Manganese Carbonate and Ammonium Molybdate Tetrahydrate. J Therm Anal Calorim. 2000;59:961-970.

[33] Murugan R, Chang $\mathrm{H}$. Thermo-Raman investigations on thermal decomposition of $\left(\mathrm{NH}_{4}\right)_{6} \mathrm{Mo}_{7} \mathrm{O}_{24} \cdot 4 \mathrm{H}_{2} \mathrm{O}$. J Chem Soc Dalton Trans. 2001;20:3125-3132.

[34] Shaheen WM. Thermal behaviour of pure and binary basic nickel carbonate and ammonium molybdate systems. Mater Lett. 2002;52:272-282.

[35] Wienold J, Jentoft RE, Ressler T. Structural Investigation of the Thermal Decomposition of Ammonium Heptamolybdate by in situ XAFS and XRD. Eur J Inorg Chem. 2003;1058-1071.

[36] Radwan NRE, Mokhtar M, El-Shobaky GA. Thermal behaviour of ammonium molybdate-basic magnesium carbonate system doped with lithium nitrate. J Therm Anal Calorim. 2003;71:977986.

[37] Manukyan K, Davtyan D, Bossert J, Kharatyan S. Direct reduction of ammonium molybdate to elemental molybdenum by combustion reaction. Chem Eng J. 2011;168:925-930.

[38] Biedunkiewicz A, Krawczyk M, Gabriel-Polrolniczak U, Figiel P. Analysis of $\left(\mathrm{NH}_{4}\right)_{6} \mathrm{Mo}_{7} \mathrm{O}_{24} \cdot 4 \mathrm{H}_{2} \mathrm{O}$ thermal decomposition in argon. J Therm Anal Calorim. 2014;116:715-726.

[39] Gaigneaux EM, Genet MJ, Ruiz P, Delmon B. Catalytic Behavior of Molybdenum Suboxides in the Selective Oxidation of Isobutene to Methacrolein. J Phys Chem B. 2000;104:5724-5737.

[40] Sebenik RF, Burkin AR, Dorfler RR, Laferty JM, Leichtfried G, Meyer-Grünow H, Mitchell PCH, Vukasovich MS, Church DA, Van Riper GG, Gilliland JC, Thielke SA. Molybdenum and Molybdenum Compounds. in Ullmann's Encyclopedia of Chemical Technology. Weinheim: Wiley-VCH; 2005.

[41] Alizadeh S, Hassanzadeh-Tabrizi SA. Ceram Int. 2015;41:10839-10843.

[42] Szilágyi IM, Madarász J, Hange F, Pokol G. Partial thermal reduction of ammonium paratungstate tetrahydrate. J Therm Anal Calorim. 2007;88:139-144.

[43] Hunyadi D, Sajó I, Szilágyi IM. Structure and thermal decomposition of ammonium metatungstate. J Therm Anal Calorim. 2014;116:329-337.

[44] Chianga TH, Hob PY, Chiub SY. Chaob AC. Synthesis, characterization and photocatalytic activity of $\alpha-\mathrm{MoO} 3$ particles utilizing different polyol monomers under visible light irradiation. $\mathrm{J}$ Alloy Comp. 2015;651:106-113.

[45] Szilágyi IM, Santala E, Heikkilä M, Kemell M, Nikitin T, Khriachtchev L, Räsänen M, Ritala M, Leskelä M. Thermal study on electrospun polyvinylpyrrolidone/ammonium metatungtate nanofibers: Optimising the annealing conditions for obtaining $\mathrm{WO}_{3}$ nanofibers. $\mathrm{J}$ Therm Anal Calorim. 2011;105:73-81. 
[46] Madarász J, Szilágyi IM, Hange F, Pokol G. Comparative evolved gas analyses (TG-FTIR, TG/DTA-MS) and solid state (FTIR, XRD) studies on thermal decomposition of ammonium paratungstate tetrahydrate (APT) in air. J Anal Appl Pyrol 2004;72:197-201.

[47] Szilágyi IM, Madarász J, Pokol G, Király P, Tárkányi G, Saukko S, Mizsei J, Tóth AL, Szabó A, Varga-Josepovits K. Stability and controlled composition of hexagonal $\mathrm{WO}_{3}$. Chem Mater 2008;20:4116-4125.

[48] Range KJ, Zintl R. The Thermal Decomposition of Ammonium Metavanadate(V) in Open and Closed Systems. Z Naturforsch 1988;43:309-317.

[49] Kótai L, Sajó IE, Jakab E, Keresztury G, Németh C, Gács I, Menyhárd A, Kristóf J, Hajba L, Petrusevski VM, Ivanovski V, Timpu D, Sharma PK. Studies on the Chemistry of $\left[\mathrm{Cd}\left(\mathrm{NH}_{3}\right)_{4}\right]\left(\mathrm{MnO}_{4}\right)_{2}$. A Low Temperature Synthesis Route of the $\mathrm{CdMn}_{2} \mathrm{O}_{4+\mathrm{x}}$ Type $\mathrm{NO}_{\mathrm{x}}$ and $\mathrm{CH}_{3} \mathrm{SH}$ Sensor Precursors. Z Anorg Allg Chem 2012;638:177-186.

[50] Kótai L, Gács I, Sajó IE, Sharma PK, Banerji KK. Beliefs and facts in permanganate chemistry an overview on the synthesis and and the reactivity of simple and complex permanganates. Trend Inorg Chem 2009;11:25-104.

[51] Kótai L, Baneri KK, Sajo IE, Kristóf J, Sreedhar B, Holly S, Keresztury G, Rockenbauer A. An Unprecedented-Type Intramolecular Redox Reaction of Solid Tetraamminecopper(2+) Bis(permanganate) $\left(\left[\mathrm{Cu}\left(\mathrm{NH}_{3}\right)_{4}\right]\left(\mathrm{MnO}_{4}\right)_{2}\right)$ - A Low-Temperature Synthesis of Copper Dimanganese Tetraoxide-Type $\left(\mathrm{CuMn}_{2} \mathrm{O}_{4}\right)$ Nanocrystalline Catalyst Precursors. Helvet Chim Acta 2002;85:2316-2327.

[52] Sajo IE, Kótai L, Keresztury G, Gács I, Pokol G, Kristóf J, Soptrayanov B, Petrusevski VM, Timpu D, Sharma PK. Studies on the Chemistry of Tetraamminezinc(II) Dipermanganate $\left(\left[\mathrm{Zn}\left(\mathrm{NH}_{3}\right)_{4}\right]\left(\mathrm{MnO}_{4}\right)_{2}\right)$ : Low-Temperature Synthesis of the Manganese Zinc Oxide $\left(\mathrm{ZnMn}_{2} \mathrm{O}_{4}\right)$ Catalyst Precursor. Helvet Chim Acta 2008;91:1646-1658.

[53] Hunyadi D, Ramos ALVM, Szilágyi IM. Thermal decomposition of ammonium tetrathiotungstate. J Therm Anal Calorim. 2015;120:209-2015. 


\section{Figures}
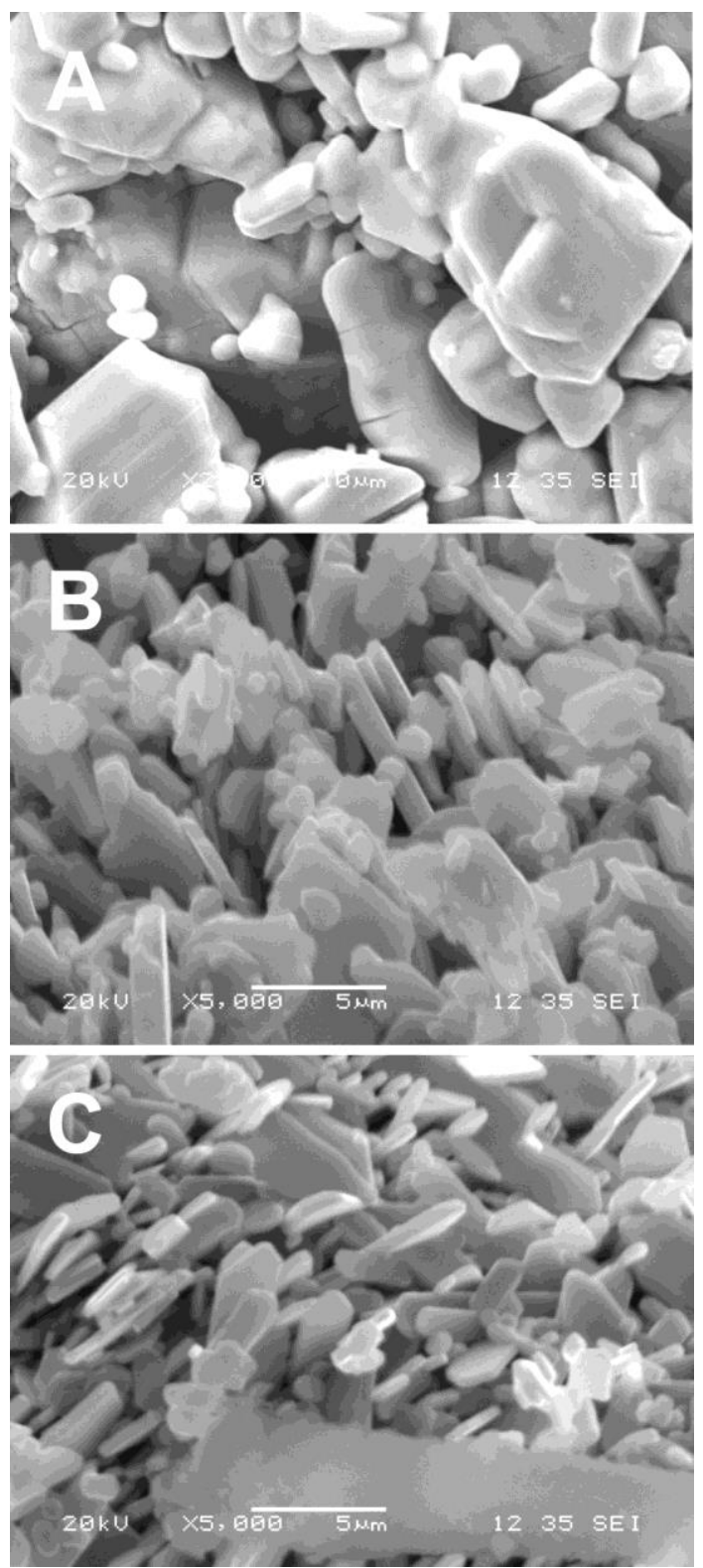

Figure 1. SEM images of (a) 1; (b) 1 annealed in $\mathrm{N}_{2}$ at $700{ }^{\circ} \mathrm{C}$; (c) $\mathbf{1}$ annealed in air at $700{ }^{\circ} \mathrm{C}$ 


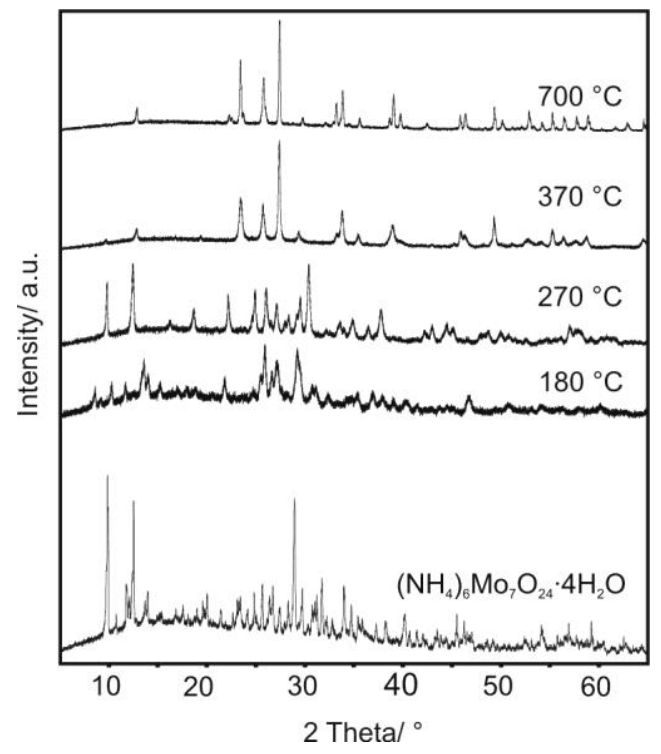

Figure 2. XRD patterns of $\mathbf{1}$ and its decomposition products in $\mathrm{N}_{2}$

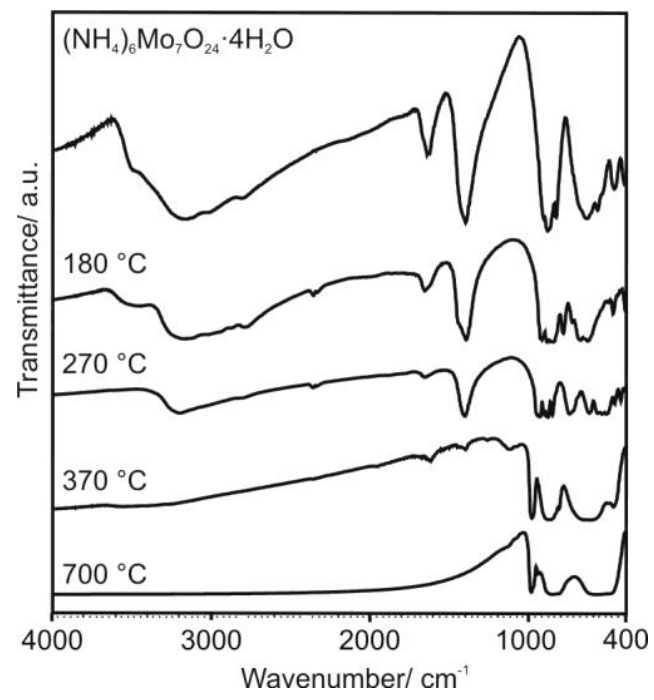

Figure 3. FTIR spectra of $\mathbf{1}$ and its decomposition products in $\mathrm{N}_{2}$ 


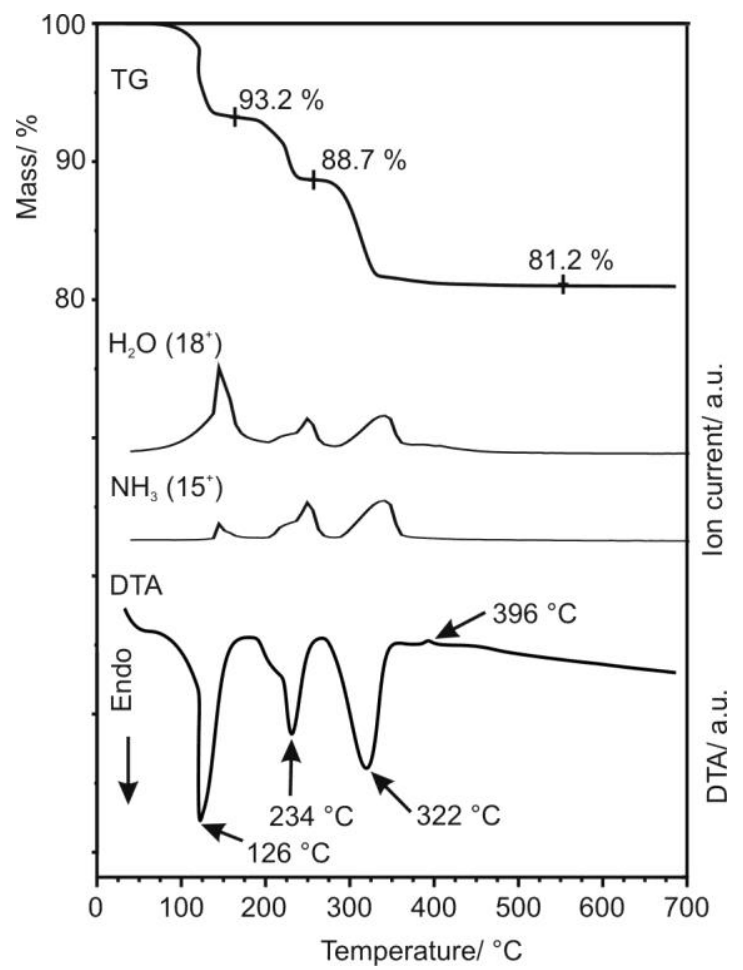

Figure 4. TG/DTA and EGA-MS curves of $\mathbf{1}$ in $\mathrm{N}_{2}$ 


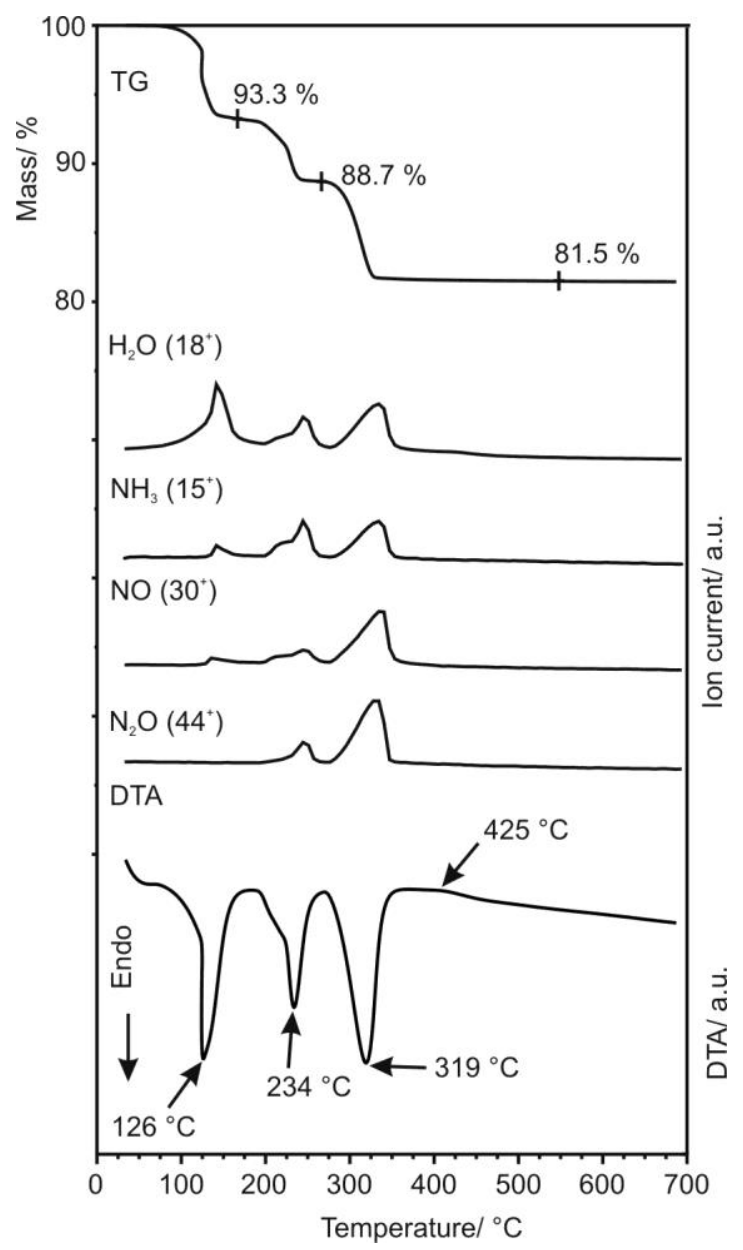

Figure 5. TG/DTA and EGA-MS curves of 1 in air

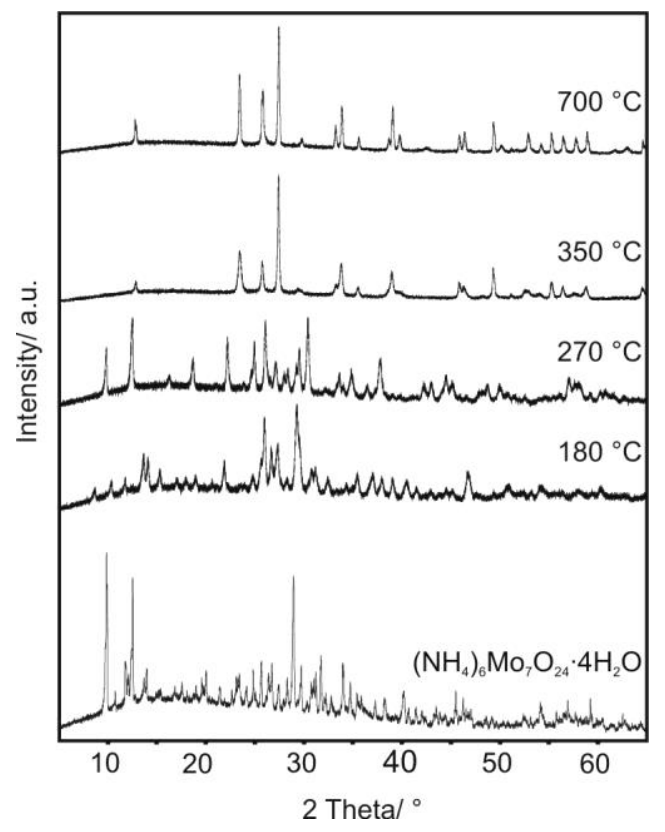

Figure 6. XRD patterns of $\mathbf{1}$ and its decomposition products in air 


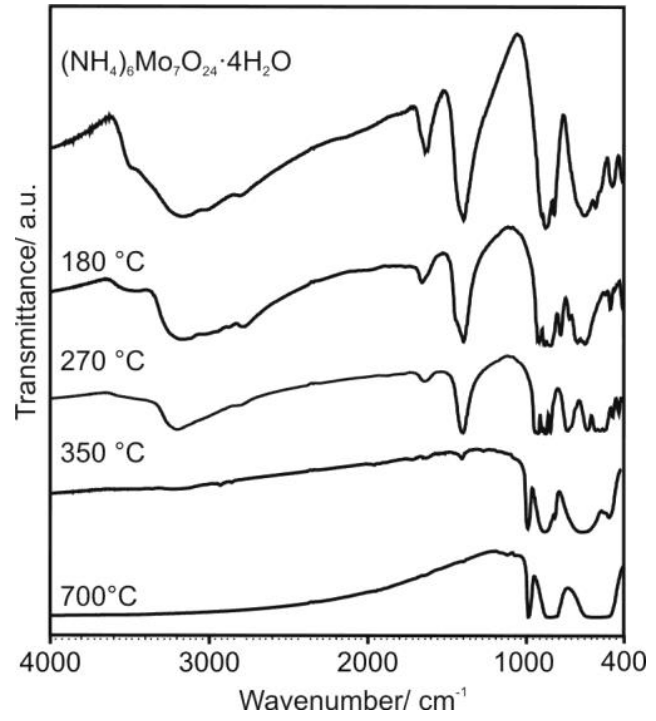

Figure 7. FTIR spectra of $\mathbf{1}$ and its decomposition products in air 

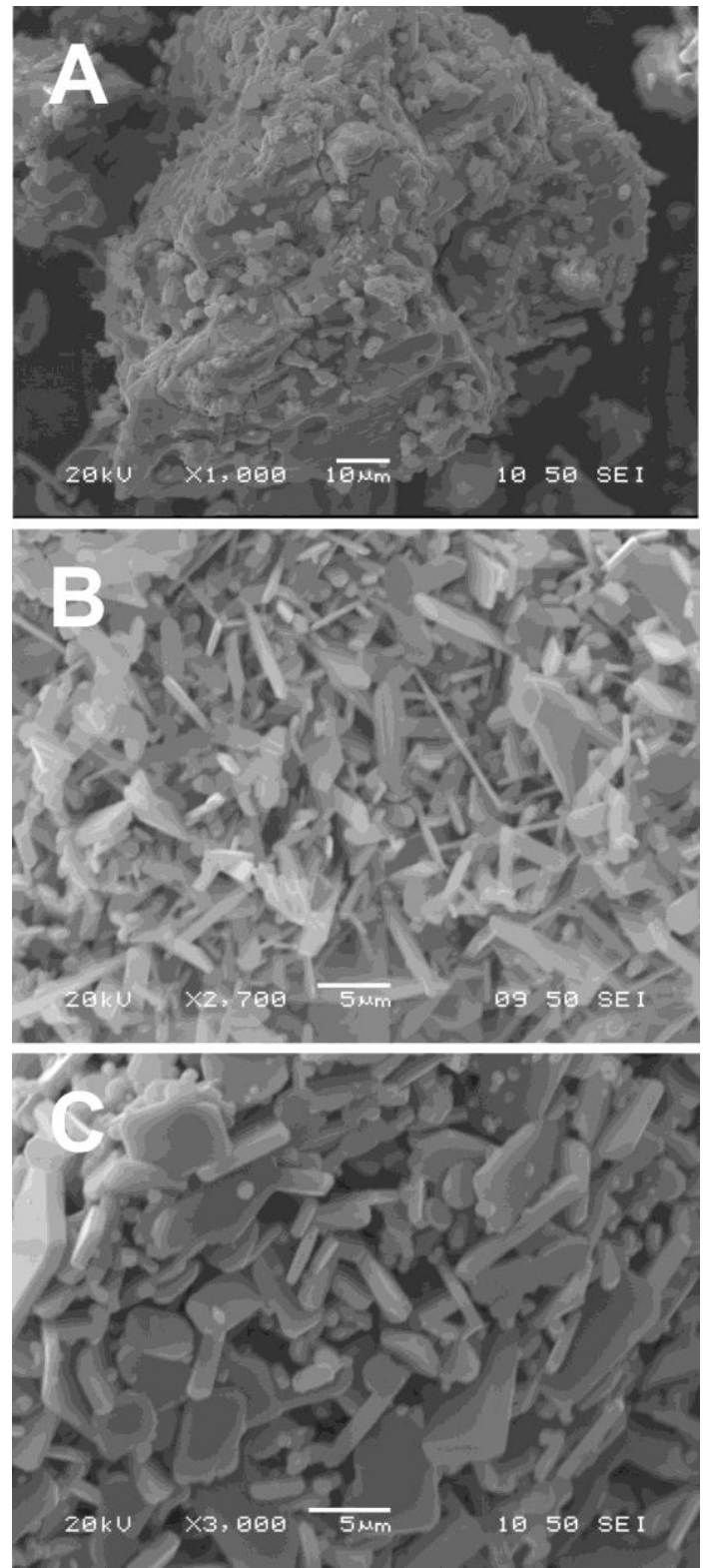

Figure 8. SEM images of (a) 2; (b) 2 annealed in $\mathrm{N}_{2}$ at $700{ }^{\circ} \mathrm{C}$; (c) 2 annealed in air at $700{ }^{\circ} \mathrm{C}$ 


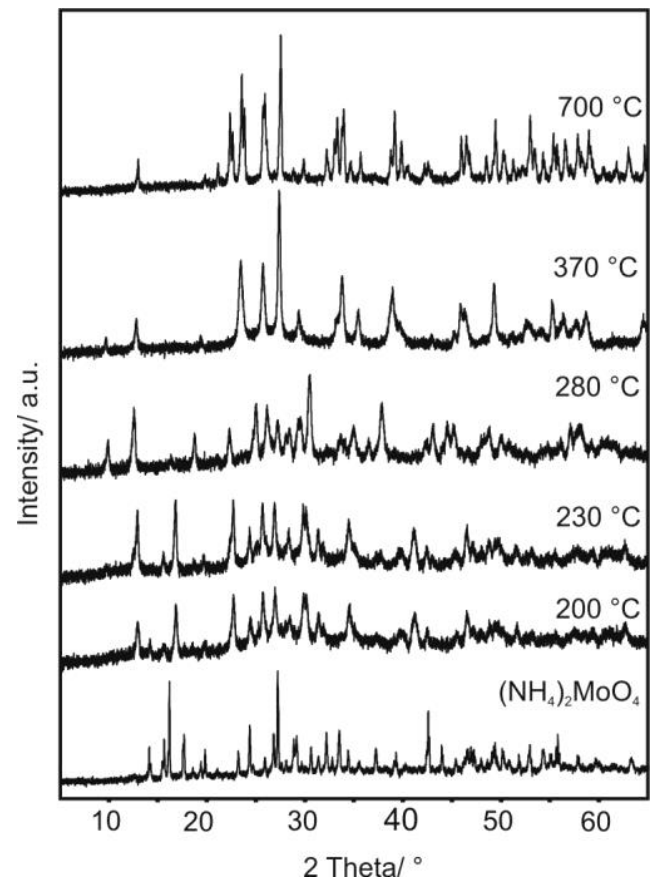

Figure 9. XRD patterns of $\mathbf{2}$ and its decomposition products in $\mathrm{N}_{2}$

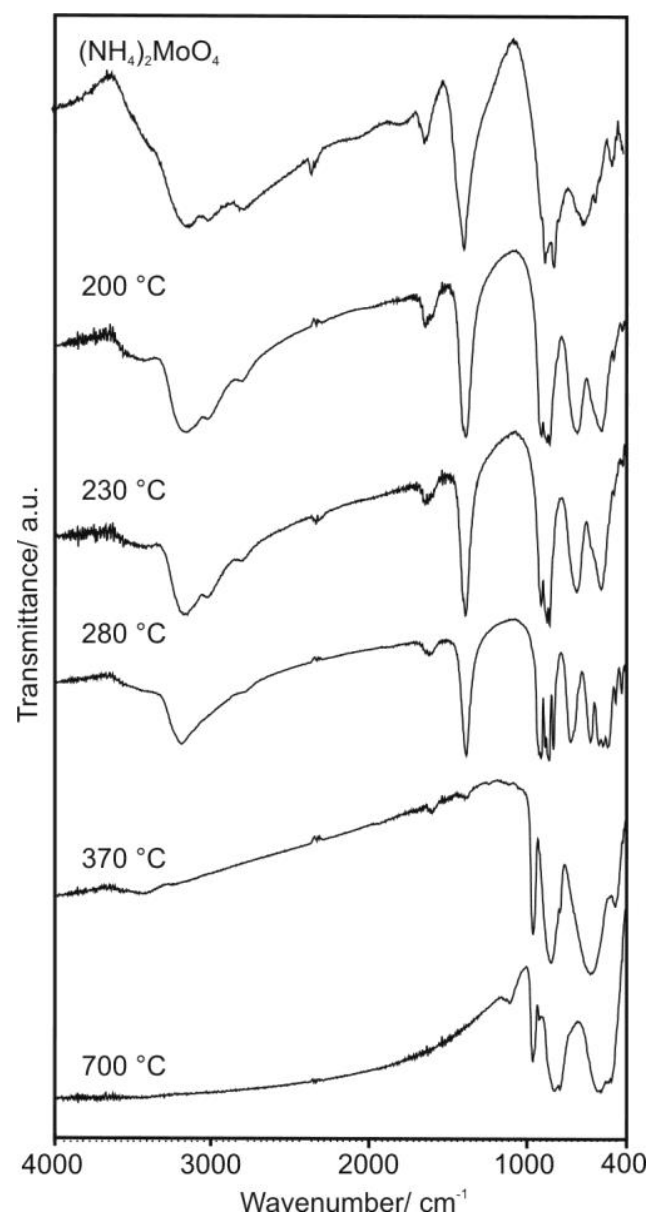

Figure 10. FTIR spectra of $\mathbf{2}$ and its decomposition products in $\mathrm{N}_{2}$ 


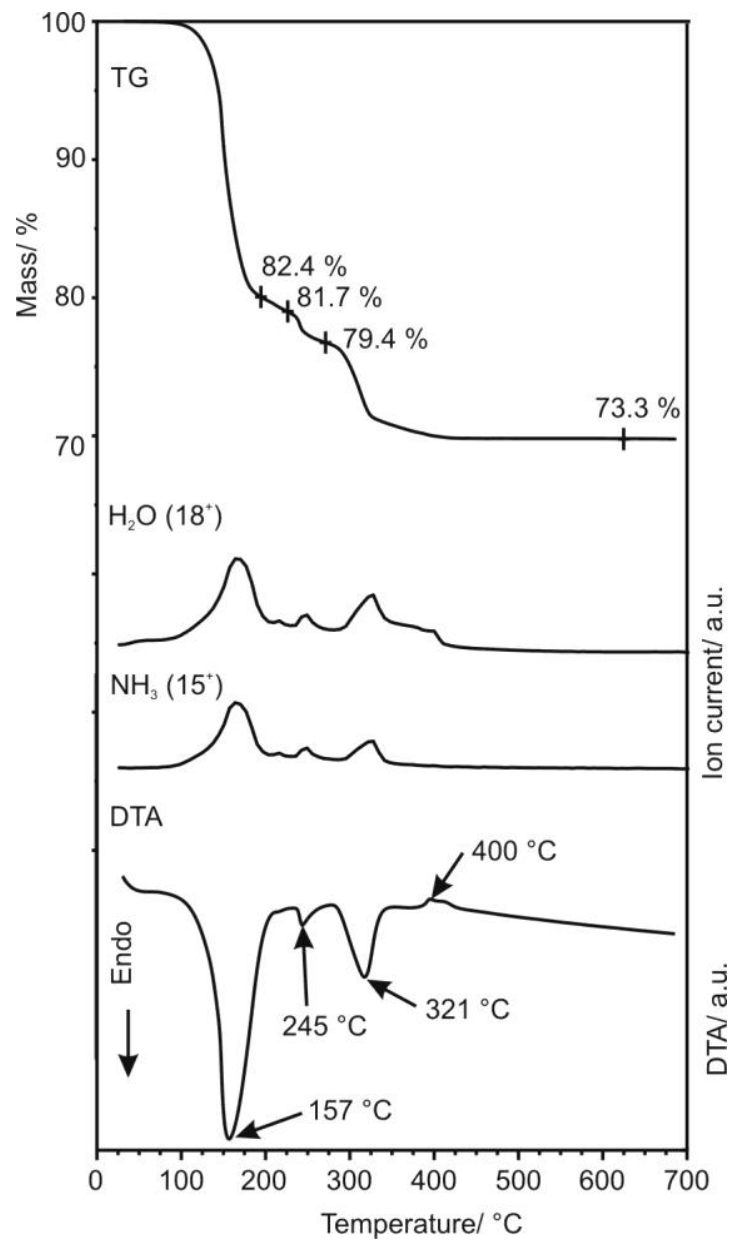

Figure 11. TG/DTA and EGA-MS curves of 2 in $\mathrm{N}_{2}$ 


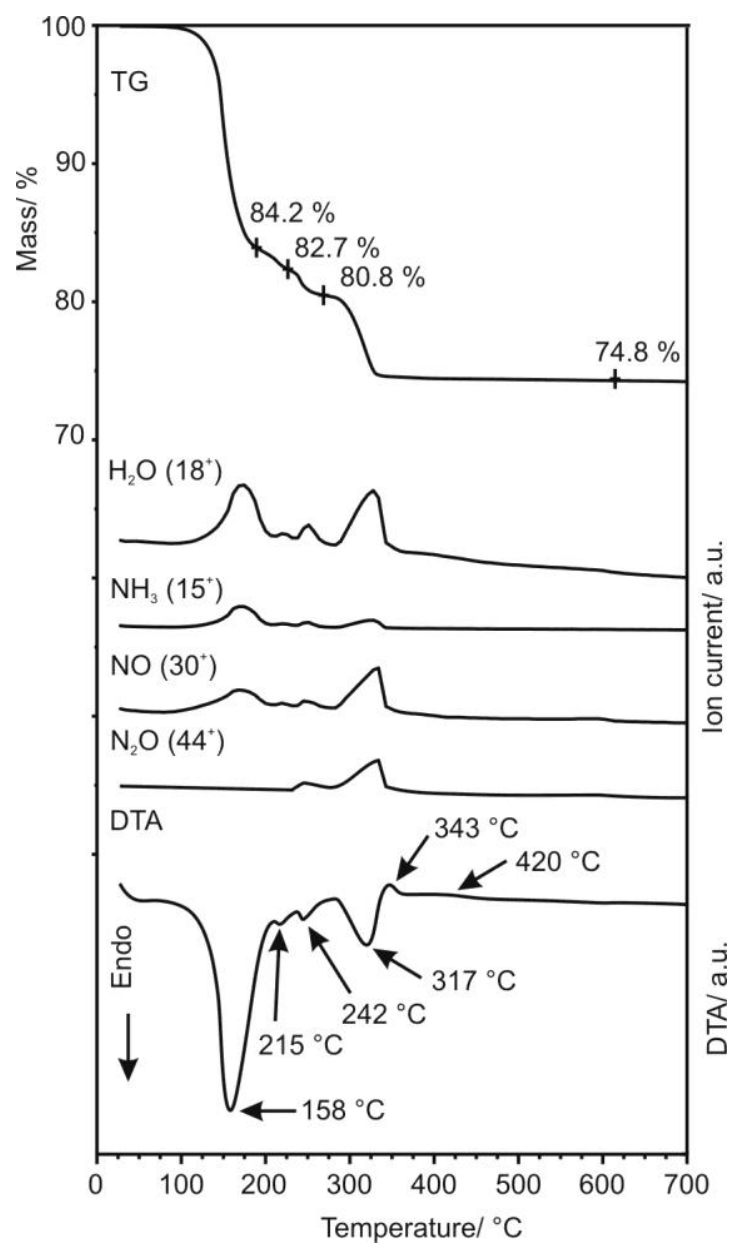

Figure 12. TG/DTA and EGA-MS curves of 2 in air

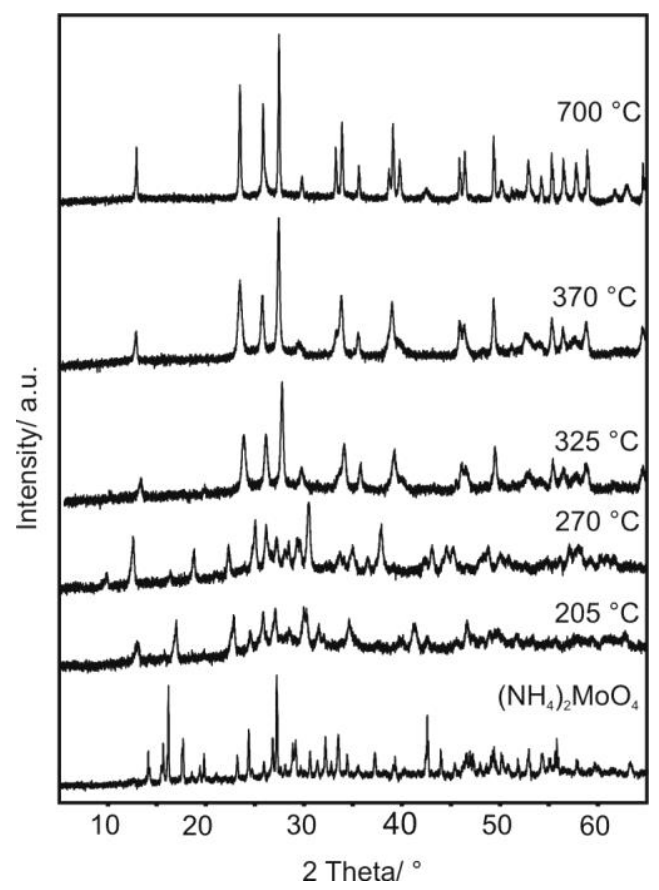

Figure 13. XRD patterns of $\mathbf{2}$ and its decomposition products in air 


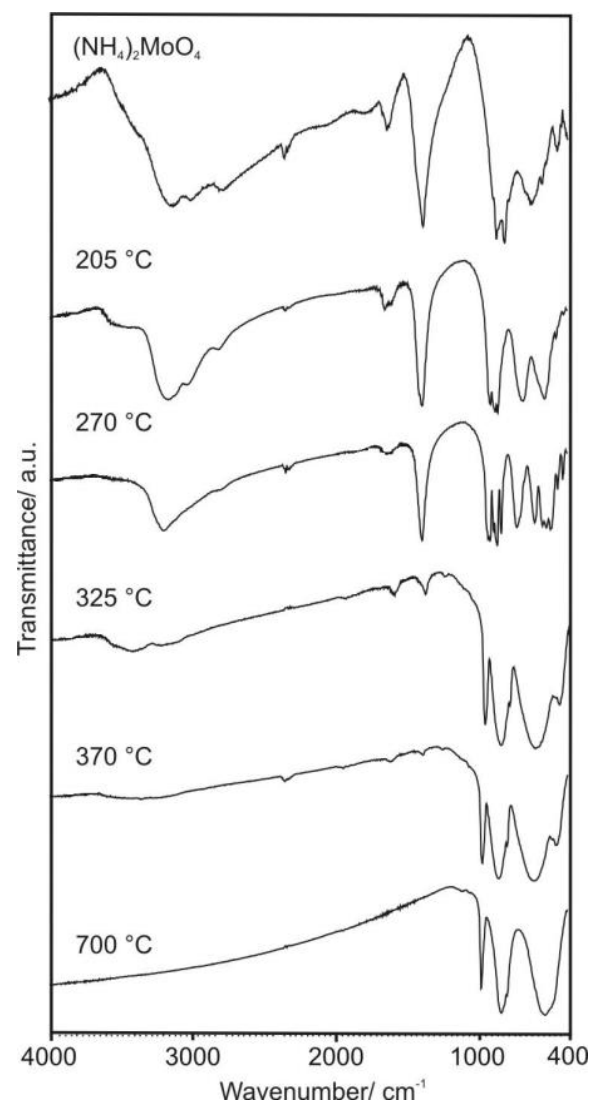

Figure 14. FTIR spectra of 2 and its decomposition products in air 